NEWS

\title{
Outcry over scientists' dismissal
}

\section{Following years of acrimony, two high-profile researchers in Mexico have been expelled from their institute.}

To the scores of scientific luminaries who support them, the Terrones brothers are two of the brightest stars of Mexican science and have raised the nation's profile in nanotechnology. Yet the federal Institute for Scientific and Technological Research of San Luis Potosí (IPICYT) fired Humberto and Mauricio Terrones Maldonado in December, and their future in their home country is now looking dim.

International science leaders say that the case serves as an example of how entrenched scientific bureaucracies in developing nations can drive away promising researchers, especially those who have been trained abroad.

"This is a major loss for Mexican science," says Mildred Dresselhaus, a nanotechnology researcher at the Massachusetts Institute of Technology (MIT) in Cambridge and a former president of the American Association for the Advancement of Science, who has advocated on behalf of the Terrones.

David Ríos Jara, IPICYT's director, rejects these arguments. "The foreign scientists' perception that Mexican science is in imminent peril is a flat misconception," he says, adding that "there are about 20,000 researchers in the country carrying out high-quality research in many areas".

Ríos says that he was forced to terminate the employment of the brothers because they had violated institute rules and Mexican laws. Scientists outside Mexico have heard only one side of the story, he says.

After receiving their doctorates in the United Kingdom and doing postdoctoral work abroad, the Terrones returned to Mexico and established the country's first nanotech lab, located at IPICYT, about a decade ago. They secured several large grants, collaborated with top researchers abroad and published well-cited papers on carbon nanotubes and buckyballs in high-impact journals.

But several years ago, disagreements arose between the Terrones and the administration at IPICYT over the operation of their lab (see Nature 454, 143; 2008). Tensions between the two sides came to a head late last year, and

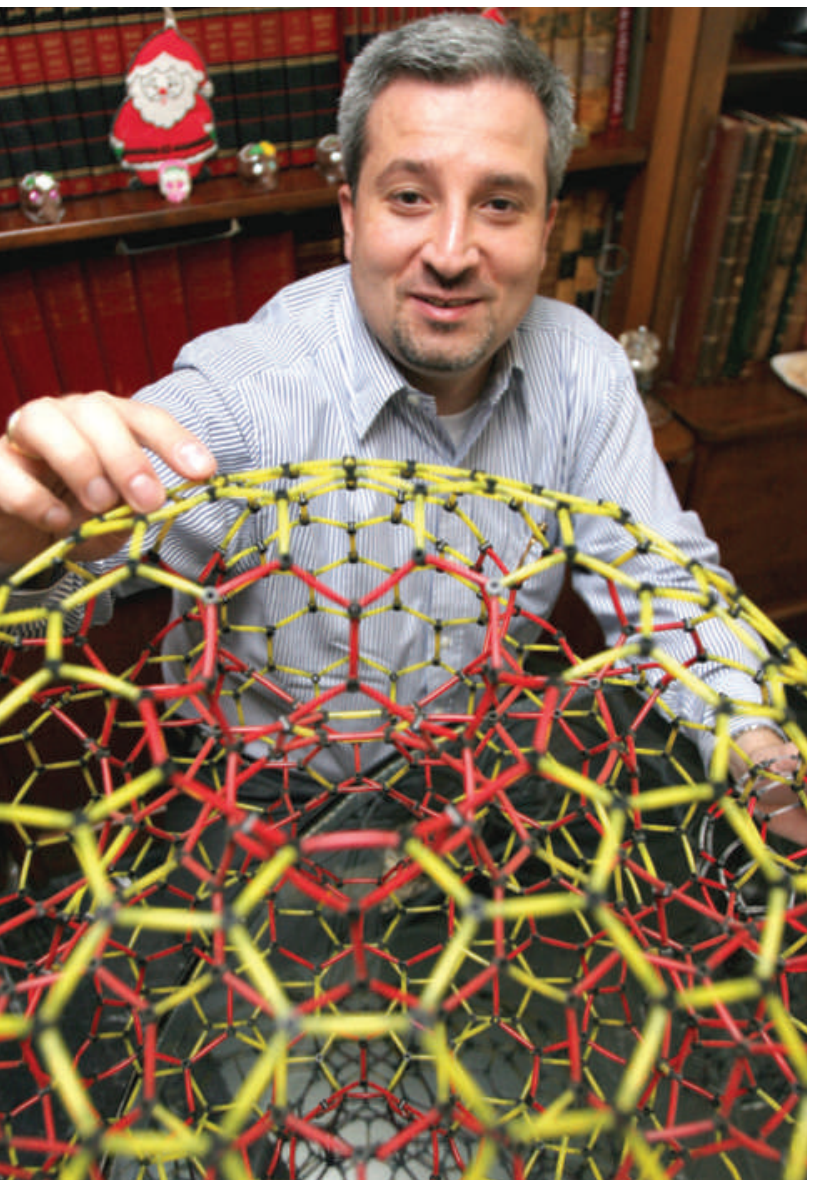

winners of the Nobel Prize in Chemistry. They unsuccessfully lobbied for a compromise with Mexican President Felipe Calderón Hinojosa and other top officials. Kroto and some 70 other scientists are again petitioning in support of the brothers (see Correspondence from H. W. Kroto et al., page 160).

The appeals by researchers outside Mexico have not calmed the situation. In a written response to enquiries from Nature, Rosaura Ruiz Gutiérrez, president of the Mexican National Academy of Science, said that the letter sent to President Calderón in 2008 "created a great deal of unease in the Mexican scientific community, since its arguments lack sufficient knowledge of the regulations in Mexican institutions". Ruiz said the case has divided the Mexican scientific community and that "proper channels exist for resolving this disagreement".

Some are pessimistic about the chances for resolving the dispute. Ljubisa Radovic is a Spanish-speaking materials scientist at Pennsylvania State University in University Park who visited San Luis Potosí in an unsuccessful attempt to broker a compromise. He blames the impasse on the IPICYT administration. "If you have stars like the Terrones," he

the brothers were expelled from their lab in December.

"I won't work in a developing nation again," says Mauricio. "Other Mexican universities are afraid to hire us," adds Humberto.

\section{Centre of attention}

In an e-mail to Nature on 25 February, Ríos accuses the brothers of several "irregularities": failing to include IPICYT in four technology patent applications, not securing proper authority to travel extensively last year and improperly working for a private university. The Terrones deny any impropriety and blame professional jealousy for their firing, a charge that Ríos rejects.

In 2008, the Terrones brothers' situation attracted the attention of prominent scientists, including British researcher Harold Kroto and Mexico's Mario Molina, both says, "you take care of them."

Dresselhaus got a personal view of the escalating conflict in mid-December, when she visited IPICYT to participate in the doctoral defence of Jessica Campos-Delgado, one of the Terrones' students. An unusual number of uniformed guards were present, apparently to head off a disturbance by students supporting the Terrones, according to the brothers and Campos. The Terrones were intermittently called away for discussions with their lawyers and administrators. Around that time, their e-mail accounts were shut down, and by the end of December, their pay cheques stopped coming. "The whole event was bizarre," says Dresselhaus.

Kroto, who oversaw Mauricio's doctorate at the University of Sussex in Brighton, UK, says that he worries about the Terrones' remaining students. In an e-mail addressed to the "International Community" in late January, several 
students and staff in the Terrones' nanotech group said "we remain extremely worried that we might be fired on a whim" and that they had been pressured to retract their criticisms of the administration.

Ríos says that the IPICYT administration has offered its full support to the remaining students. The current students declined interview requests from Nature.

Campos, who received her degree, says that she remains shaken by the Terrones' firing. She will soon leave Mexico and head for a postdoctoral fellowship in Brazil. "I don't know if I can or will return, if I have to deal with the people who did this," she says.

That will be a loss for Mexico. During her doctoral training, Campos spent six months in Dresselhaus's lab at MIT, providing a key contribution to a method to enhance graphene nanoribbons for mass production as semiconductors (X. Jia et al. Science 323, 1701-1705; 2009). MIT, in conjunction with IPICYT, applied for a US patent application on the technology, and MIT now is seeking licensing agreements.

\section{Helpful discussions}

Two of the patents that Ríos says the Terrones failed to disclose involve Mexico's largest juice producer, Grupo Jumex in Tulpetlac. The other two are owned by institutions in Japan: the National Institute for Materials Science (NIMS) in Tsukuba and Shinshu University in Wakasato.

The science for the patents was "partly or fully developed" at IPICYT, Ríos wrote, and "it goes without saying how serious stealing intellectual property is".

Gerd Reiband, a head engineer at Jumex, says that the company filed the two patent applications on its own because the work was conducted there, not at IPICYT. There was no agreement to financially reward the Terrones and their names were included as a courtesy for their helpful discussions. Scientists at the two Japanese institutions say similar conditions applied to their patents.

Ajayan Vinu, a materials scientist at NIMS, worked with Mauricio when the Mexican scientist was on a fellowship in Japan. Vinu says that he was astounded to hear that advice that Mauricio had offered had played a part in his dismissal.

"Tell them they are crazy", says Vinu, who was not contacted for details by IPICYT officials. "This is dangerous for science."

The brothers remain in San Luis Potosí and are considering legal action to fight the termination of their employment.

Rex Dalton

See Correspondence, page 160.

\section{Climate e-mail rerun}

A HIDING PLACE FOR HIV AIDS virus escapes

treatment inside progenitor blood cells.

go.nature.com/ZGu9wW

Arriving at work on 5 March, Stanford University ecologist Paul Ehrlich found a rambling and highly profane voice message from someone identifying himself as John Q Public. In one of his more lucid moments, the caller labelled Ehrlich and his colleagues in the climate-science community as "progressive communists attempting to destroy America".

Once again, a private e-mail conversation about global warming had gone public, inflaming critics and giving climate scientists yet another lesson in the challenge of responding effectively.

Several days earlier, Ehrlich had taken part in an informal discussion with leading climate researchers on a National Academy of Sciences e-mail list. They were exploring how climate scientists should respond to a recent US Senate report on the 'Climategate' e-mails leaked late last year from the University of East Anglia in the United Kingdom. In the 23 February report, Senator James Inhofe (Republican, Oklahoma), who has long been the leading sceptic in Congress, accused at least 17 climate scientists of unethical, even potentially criminal, behaviour in their handling of climate data.

The researchers' private - and quite spirited - discussion was soon disclosed in conservative media outlets. The initial story, which ran in The Washington Times, quoted Ehrlich as saying that climate scientists must recognize they are in a "street fight against well-funded, merciless enemies who play by entirely different rules". Other participants went so far as to suggest taking out advertisements to counter the sceptics, perhaps through a new non-profit organization.

Ehrlich stands by his statement, but says the affair has made it "crystal clear" that there is no such thing as a private e-mail. "I'm not putting anything in an e-mail that I don't want to appear on the front page of The Washington Times or Fox News," he says, adding that the sceptics "are trying to keep the scientists busy and to keep the scientists from doing their job, and they are doing extremely well".

Stephen Schneider, a climatologist at Stanford University in California who is on Inhofe's list and participated in the National Academy discussion, says he is urging colleagues to calm down and stick to the science. And he hopes that the Inhofe report - which says the scientists "violated fundamental ethical principles governing taxpayer-funded research and, in some cases, may have violated federal laws" will spark a backlash. "If we don't have civil discourse, where reality rather than spin is the basis of decisions, how are we going to function as a society?" Schneider asks.

Yet Schneider himself compares Inhofe to the infamous Senator Joe McCarthy, who led the discredited campaign against communists during the 1950s. Inhofe spokesman Matt Dempsey calls the comparison "flat out false" and says the report merely lists a number of laws - including the Freedom of Information Act and the False Claims Act - that the scientists might have violated. Inhofe has asked the inspectors general of a number of federal science agencies to determine whether iolations actually occurred.

As a member of the minority party, Inhofe can't do much more than issue statements and reports. But Schneider says that if the Republicans later regain a majority in the Senate, Inhofe could take more concrete steps, such as forcing climate scientists to testify before Congress and pursuing his claims in congressional hearings.

Scientific societies, including the American Association for the Advancement of Science (AAAS) and the American Geophysical Union, should respond to Inhofe's report with a declaration of support, says Michael Oppenheimer, a climate scientist at Princeton University in New Jersey who is also on Inhofe's list. "Defending the scientific community and scientists from attacks ought to be a central part of their mission."

The AAAS and other scientific organizations have repeatedly affirmed the fundamental science of global warming, but some officials are wary of responding directly to Inhofe. Alan Leshner, AAAS chief executive, says he is focused on trying to ensure that policy-makers distinguish between the controversies and the science. "What I don't want to see is that this set of incidents is used as an excuse to deny the scientific findings."

Jeff Tollefson

See Editorial, page 141. 